Piotr Prósinowski, Piotr Krzywdziński

Uniwersytet Gdański

\title{
Oniryczne inkarnacje: konstrukcje snów w wybranych grach wideo
}

\author{
Wstęp. \\ Sny, kultura i media
}

Sny stanowią niewyczerpane źródło inspiracji dla tekstów kultury. Fascynacja nimi wydaje się mieć nie tylko charakter zainteresowania obcością i odmiennością onirycznych doświadczeń względem tych znanych z rzeczywistości. Towarzyszy im również głęboko zakorzenione w kulturze przeświadczenie, że sny mają swą własną, unikatową funkcję przekazywania wiedzy niedostępnej nam w inny sposób; archetypiczne przedstawienia snów pokazują, że poprzez zanurzenie w ich świat zyskujemy dostęp do nowych form autorefleksji, zdolności profetycznych czy prawd, które w innych okolicznościach pozostają ukryte.

O snach opowiadają różne teksty kultury. Można tu podać przykłady ze sztuk plastycznych (na przykład rycina Francisca de Goi Kiedy rozum śpi, budza się potwory czy obraz olejny Nocna Mara Johanna Heinricha Füssliego), literatury (Sen George'a Gordona Byrona czy współczesna powieść fantastyczna Jonathan Strange i pan Norrell Susanny Clarke), kinematografii (Incepcja w reżyserii Christophera Nolana czy ciekawe wykorzystanie snu w produkcji Oczy szeroko zamknięte Stanleya Kubricka). Także nauka - zwłaszcza psychologia (Freud 1996) i kulturoznawstwo (Topp, Fereński, Nahirny 2014) - często sięga do przedstawień sennych.

W artykule pragniemy ukazać, w jaki sposób gry wideo posługują się zakorzenionymi w kulturze wyobrażeniami dotyczącymi marzeń sennych. Wskazujemy przy tym na mechanizmy ich adaptacji do mechaniki rozgrywki i fabuły oraz opisujemy, jak gry wykorzystują dostępne im środki stylistyczne do ukazania snów w nowej formie. Poddajemy także analizie przykładowe gry, w których marzenia senne stanowiły szczególnie istotny aspekt rozgrywki. Ponadto wskazujemy, w jakiej sytuacji stawia to odbiorcę (gracza) wobec konkretnych wyobrażeń dotyczących snów.

Jesteśmy zdania, że temat ten jest istotny nie tylko z perspektywy wiedzy o kulturze współczesnej, ale także dla tych nauk społecznych, których zainteresowanie związane jest ze społeczną transmisją wiedzy, wyobrażeń i symboli, ze szczególnym uwzględnieniem socjologii i pedagogiki kultury. 


\section{Sny w grach wideo - ekspozycje i konstrukty}

Gry wideo przez długi czas zmieniały się i rozwijały wraz z postępem technologicznym. Podczas gdy wielu dorosłych badaczy kojarzy ten rodzaj wirtualnej rozrywki z produkcjami takimi jak Mario, duża część rynku gier oferuje produkty bardziej rozbudowane, wielowątkowe i kompleksowe, o zróżnicowanej jakości.

Operowanie konstrukcjami onirycznymi jest jednym z wykorzystywanych przez gry (i ich twórców) środków przekazu - to właśnie te konstrukcje są głównym przedmiotem naszego zainteresowania. Wybierając kilka przykładowych produkcji, chcemy pokazać środki, dzięki którym gry wideo adaptują złożoną symbolikę, oraz sposób postrzegania szczególnego, ludzkiego doświadczenia, jakim są marzenia senne.

\section{Wielkość i samozagłada - profetyczne wizje senne w sadze Baldur's Gate}

Baldur's Gate I oraz Baldur's Gate II to gry zaliczane do klasycznych tytułów, które pomogły zdefiniować gatunek cRPG, oraz na długie lata wyznaczyły kierunek jego rozwoju. Wraz z dwoma dodatkami (po jednym do każdej z części) opowiadają historię młodego bohatera, który dowiaduje się, że jest potomkiem zmarłego bóstwa - Bhaala, lokalnego patrona mordu i skrytobójstwa.

W obu częściach sagi sny odgrywają istotną rolę fabularną. Stanowią komentarz do aktualnej sytuacji głównego bohatera, prezentują jego obawy i wątpliwości i dość często zapowiadają przyszłe wydarzenia. Stawiają pytania o to, jak postąpimy w decydujących momentach gry, prezentują rzeczywiste i wyobrażone konsekwencje naszych wyborów.

Sny głównej postaci przybierają często charakter profetyczny; zawierają bogatą symbolikę, a do jej odczytania i zrozumienia potrzeba wiedzy na temat uniwersum, w którym toczy się rozgrywka. Szczególnie w pierwszej części cyklu często przewijają się obrazy posągów (niekiedy porozbijanych), kościanego sztyletu (atrybutyczny oręż boskiego przodka protagonisty) czy też wizje bycia pochłanianym przez ziemię. Sny towarzyszące głównej postaci są zwykle mroczne, niespokojne, przepojone lękiem, a niekiedy też mniej lub bardziej wyrazistą agresją. Miewają niekiedy charakter fatalistyczny - towarzyszy im poczucie nieuchronności nadchodzących zdarzeń, ostatecznej klęski, braku możliwości odmiany przypisanego nam losu.

W snach bohater konfrontuje się ponownie z wcześniej pokonanymi przeciwnikami - ku swemu zdumieniu odkrywa nowy wymiar podjętych już akcji. Często dużo donioślejszy i bardziej ponury niż poza snem.

Tam, gdzie rzeczywistość rozgrywki wymusza na postaci walkę, choćby i przez nas niepożądaną - tam we śnie akt przemocy i agresji może być ukazany jako dobrowolny wybór. Jakby to świadomie podjęte przez nas działania były złudzeniem stanowiącym próbę moralnego usprawiedliwienia wyrządzanego przez nas zła. Ten wątek pojawia się zresztą w grach także poza sferą marzeń sennych.

Niekiedy wygląda to tak, jakby gra zadawała pytanie samemu graczowi o zasadność podejmowanych przez niego akcji. Nawet jeśli wydaje się, że jego decyzje były dobre i szlachetne, to czy nie jest czasem tak, że stanowią one tylko 
zasłonę dymną dla zaspokajania przez Dziecię Bhaala pragnienia walki, mordu i zniszczenia?

Charakterystyczne jest to, że marzeniom sennym - zwłaszcza tym, w których jest obecna przemoc i zniszczenie - towarzyszą wizje ostatecznej autodestrukcji. Nierzadko sami zostajemy więc pochłonięci przez zło, które - jako protagonista - uwalniamy.

W grze sny zapowiadają istotne zmiany dotykające naszą postać. Na ich skutek otwieramy dostęp do nowych zdolności, lepiej poznajemy siebie i naszą sytuację, otwieramy ścieżki interpretacji fabuły bądź dodatkowe opcje dialogowe z naszymi towarzyszami.

Przestrzeń marzeń sennych jawi się jako rzeczywistość mistyczna. Jest nie tylko symboliczną reprezentacją tego, czego doświadczamy - lecz autonomiczną przestrzenią, która rządzi się własnymi prawami, pozwala na działanie i wywiera silny wpływ na głównego bohatera. Wydaje się, że szczególną rolą tych doświadczeń jest rodzaj mistycznej przemiany postaci, która uzyskuje nowe cechy poprzez stopniowe oddalanie się od swego pierwotnego stanu. W snach tych śmierć $\mathrm{i}$ zniszczenie idą ramię $\mathrm{w}$ ramię $\mathrm{z}$ odtworzeniem $\mathrm{i}$ transformacją niczym $\mathrm{w}$ symbolice alchemicznej (Eliade 2013). Groza tych wizji leży w świadomości, że ostateczny rezultat przemian jest nieznany (i prawdopodobnie daleki od pożądanego). Transformacje przybliżają głównego bohatera do jego ponurego, boskiego, naznaczonego destrukcją dziedzictwa. Rozwój i pozyskiwanie nowych mocy - co może wydawać się z początku czymś pozytywnym - stwarza wrażenie nieuchronnego zmierzania ku ostatecznej porażce i balansowania na granicy egzystencjalnej przepaści (Bogost 2007). W przypadku intencjonalnie złych protagonistów kierunek wytyczany przez wizje staje się spełnieniem mrocznych fantazji.

Sny jako intymność i fantazja na podstawie gry wideo Neverwinter Nights 2: Maska Zdrajcy

Akcja gry Neverwinter Nights 2: Maska Zdrajcy dzieje się w tym samym uniwersum, co opisywane gry z serii Baldur's Gate, jednakże odkrywa przed graczem inny region. Jest nim Rashemen - kraina mocno utożsamiana z duchami, naturą, magią, a także snami. Zarówno w grze, jak i w książkach, których akcja dzieje się w Rashemenie, bohaterowie wykazują silne przywiązanie do śnienia oraz snów. Taką postacią jest na przykład Rashemita Fyodor znany ze Splatanych sieci (Cunningham 2004b). Mężczyzna zwykł mówić, że „są tacy, którzy myślą, i tacy, którzy śnią". Powiedzenie to pokazuje, że śnienie postrzega on jako coś odmiennego od myślenia, wyróżniającego się poznawczo. Rashemen jest kojarzone ze snami również dlatego, że wiążą się z nimi znaczące wydarzenia z powieści (Splątane sieci czy Córka mrocznego Elfa [Cunningham 2004a]) oraz w Neverwinter Night 2: Maska Zdrajcy - zwłaszcza w lokacji Coveya Kurgannis, gdzie gracz odwiedza Sabat Śpiących.

Gra mocno eksponuje konstrukcje snów, w dużej mierze poprzez postać Gannayev'a, zwanego także Gann-od-Snów. Mężczyzna często wypowiada się na tematy z nimi związane, mówi o znaczeniach, które za nimi stoją, oraz o własnych doświadczeniach obcowania z marzeniami sennymi. Często kojarzy je 
z intymnością - zwłaszcza podczas rozmów z główną postacią (szczególnie, jeśli protagonistą jest kobieta). Na przykład:

Niech więc tak będzie - będziemy dzielić swe sny i świadomość. Tylko to chciałem wiedzieć. Będziemy sobie nawzajem kotwicą, gdy wokół będą szaleć burze... Nasze siły osłonią nas przed zalewającą nas powodzią chaosu. A nawet jeśli legnę, wciąż będziemy dzielić nasze uczucia, a ja pozostanę z tobą, nawet jeśli me ciało nie będzie już istnieć [...]. Moje sny dotyczą nas po tym wszystkim - są opowieścią o parze kochanków, którzy rzucili wyzwanie śmierci i powrócili do życia. Sądzę, że zasługujemy na szczęśliwe zakończenie. Taki jest mój sen. Chyba nie wymagam za wiele?

To bezpośrednie łączenie snów z namiętnością oraz innymi esencjonalnymi wartościami bliskimi człowiekowi. Dochodzi do połączenia trzech elementów: mistycyzmu, oniryzmu oraz miłości. Warto jednak pamiętać o fakcie, że gry w odróżnieniu od snów konkretnych jednostek - są tworzone z dużą intencjonalnością, nierzadko jasnymi inspiracjami oraz wpływami kulturowymi, ergo w większości prezentują popularne konstrukty płciowe i seksualne oraz operują obecnymi społecznie dyskursami (na przykład inkluzji nienormatywności, prezentowaniu tego, co tabuizowane) (Prósinowski 2015; Prósinowski, Ranachowska 2014; Cielecka 2014). Także poprzez gry, obecne w nich konstrukcje snów, romanse, mistycyzm i koneksje z wyobrażeniami społecznymi są prezentowane oczekiwania wobec kobiet, mężczyzn i ich seksualności. Można je odnieść do koncepcji rozróżnienia między animą i animusem, czyli archetypicznych cech i zachowań przypisywanych kobietom i mężczyznom (Hall, Lindzey, Campbell 2010). Ukazuje to, że oniryzm, marzenia i seksualność nie są obce cyfrowym, ludycznym przedstawieniom społecznym takim jak gry. Prezentują elementy charakterystyczne dla naszych zbiorowych wyobrażeń o grupach i rolach społecznych, o przypisanych im oczekiwaniach na poziomie dużo głębszym niż sama tylko prezentacja określonych zachowań. Przechodzą tu na poziom idealny - wyobrażeń leżących u podstaw naszego pojmowania świata oraz sposobów myślenia o nim wedle określonych kategorii (Busse-Brandyk, Chmielewska-Łuczak 2009).

Neverwinter Nights 2: Maska Zdrajcy oferuje więc fantazje - zarówno o przygodach, jak i o duchach i obcowaniu z marzeniami sennymi, z romantycznością, w pewien sposób jednocześnie przemieniając sny w coś mistycznego, tajemniczego, mocno powiązanego z magią, doświadczaniem, a także intymnością - podobnie jak w bardziej znanych literackich inkarnacjach szekspirowskich, gdzie także dochodziło do mieszania się snów z fantazją i miłością. Czy można więc powiedzieć, że gry wideo materializują sny erotyczne?

Jeśli gry dotykają archetypów płciowych, tego, co oczekiwane, jeśli ukazują to, co tabuizowane, seksualne, podniecające, to z pewnością można stwierdzić, że stają się przedstawieniem niekiedy erotycznym i intrygującym - zwłaszcza biorąc pod uwagę treści romansowe (mam tu na myśli możliwość prowadzenia wirtualnych rozmów fabularno-romantycznych protagonisty oraz stworzonej przez twórców postaci) obecne w grach (także w dużych i znanych seriach jak właśnie Neverwinter Night, Baldur's Gate czy Dragon Age). Jest to kolejna forma opowiadania o snach, fantazjach i miłości. Kultura zna wiele inkarnacji takich historii - są prezentowane w literaturze, kinematografii czy w sztukach plastycznych. Poprzez 
uobecnienie tych elementów w grach wideo daje się graczowi dostęp do nowych form ekspresji jego własnej seksualności. Pamiętając, że gracz nie jest tylko biernym odbiorcą, ale - za pośrednictwem kierowanego przez siebie awatara - także aktywnym uczestnikiem rozgrywających się zdarzeń, dysponuje on możliwością aktywnego odniesienia się do nich. Może zaangażować się (behawioralnie, emocjonalnie) lub też świadomie nabrać dystansu do tego doświadczenia. Treści romansowe w grach pozostają polem otwartym na wybory - to, czy i w jaki sposób gracz wykorzysta zaoferowane mu możliwości, zależy w dużej mierze od jego świadomych decyzji, co czyni grę przestrzenią względnie swobodnej ekspresji. To, z kim romans będzie prowadzony (jeśli w ogóle), zależy całkowicie od preferencji gracza, tego, jaka postać go zainteresuje, zaintryguje, lub którą uważa za pociągającą.

Poza wątkami dotyczącymi Ganna oraz snów nacechowanych romantycznie, w Neverwinter Nights 2: Maska Zdrajcy występują także inne przedstawienia senne, jak chociażby kolektywne rytuały śnienia: i tu ponownie sny są ukazane jako coś na swój sposób intymnego, dzielonego z bliskimi. W tym wypadku będzie to dziewięć wiedźm należących do Sabatu Śpiących, które "śpią i się nie budzą", nazywane także „Nieskończonym Snem”, przemawiające wspólnym głosem poprzez jedną z członkiń. Sabat posila się snami, wydobywa je z „najgłębszych zakamarków [umysłu - P.P., P.K.], gdzie sny mieszają się z rzeczami ukrytymi i zapomnianymi", oraz spaja w całość, by sprawować nad nimi swoją pieczę. Oto jak dalej kobiety opisują swoją rolę, śnienie oraz same sny:

Wiele rzeczy odzyskujemy ze snów śmiertelników... wizje i nadzieje, i wspomnienia. Zabieramy te rzeczy i gromadzimy je tutaj, zanim śmiertelne umysły o nich zapomną [...]. Kroczmy po ich snach i zabieramy to, co i tak utracą. [...] My gromadzimy, zbieramy, przechowujemy. Dla nas sny są skarbami, wydzieramy je tym, którzy nie znają ich wartości. Jeśli zakończysz nasz sen, to stracone zostanie wszystko, co zawiera. Wyobraź sobie... sny tysiąca tysięcy dusz, wiedza czarodziejów i królów, którzy nie żyją od wieków, nadzieje i miłości mężczyzn i kobiet, i bestii... wszystkie zawarte w naszym niekończącym się śnie.

W swojej roli wiedźmy są na swój sposób okrutne, a spotkanie gracza z nimi jest nacechowane nie tylko magią, intrygującym mistycyzmem, ale także makabrycznością. Sabat nie ukrywa swojej surowości, jest skłonny opowiadać o karach wobec tych, którzy łamią ich zasady - jedną z ukaranych była matka Ganna-od-Snów.

Podczas rozmowy można wejrzeć w tak zwaną Krainę Snów, poznać jego formę i zobaczyć prawdziwą naturę Sabatu. Kraina jest opisana jako „rozległy gobelin, po którym pełzną jędze, chciwie wyrywając fragmenty snów słabszym śmiertelnikom i wszywając je w swoją niezmierzoną sieć". Także intymności, fantazjom i wspomnieniom, jakimi są sny, może towarzyszyć swoista groza - tutaj obierająca formę niepokornych i surowych jędz, które strzegą wyrwanych śmiertelnikom strzępów marzeń sennych i wizji.

Jeszcze innym, intrygującym celem snów w analizowanej grze jest stworzenie przestrzeni do zwieńczenia rozgrywki. To tam trafiamy do wspomnianej Krainy Snów - zostaje ona miejscem, gdzie tuż przed finałową potyczką odwiedzimy senne wersje znanych graczowi lokacji. Sny więc stają się intymnym, ale 
także - w pewnym sensie - wypaczonym wspomnieniem. Ponownie zostaje ukazana dwoistość snów: ich fantazyjność, ale także groza czy też wiszące nad protagonistą fatum przeszłości. Dwoistość ta generuje kolejne pytanie: czy fantazje erotyczne, sny mówiące o tym, „co mogłoby być”, znajdują się tak daleko od tego, co było, i tanatycznych wizji możliwego końca?

Sny - czy to sensualne, erotyczne, czy niepokojące, złowieszcze - zostają nacechowane silnymi emocjami i uczuciami. Pozostawiają głębokie wrażenie bądź składają obietnice związane $\mathrm{z}$ oczekiwaniami śniącego, skłaniając w ten sposób do przemyśleń i interpretacji nie tylko samego snu, ale także elementów życia, które zostało przeżyte, lub wciąż pozostało do odkrycia.

\section{Sztuka poetyckich snów - na podstawie gry Tension autorstwa Ice-Pick Lodge}

Tension to produkcja niewielkiego, rosyjskiego studia Ice-Pick Lodge. Pozycja utrzymana w konwencji survival horroru, zrealizowana w artystyczny sposób i operująca erotyką. Akcja gry rozgrywa się w miejscu zwanym Pustką lub Niebytem - w surrealistycznym, sennym świecie, w którym kiełkuje barwna Limfa. Zadaniem gracza jest zbieranie jej w celu otwierania w swoim ciele coraz to nowych serc (co równa się ze zdobywaniem nowych zdolności), tworzenie ogrodów tętniących barwami, rozmowa z tajemniczymi Siostrami, poznanie zasad Niebytu oraz okazjonalnie walka z postaciami Braci.

Produkcja jest wypełniona mrocznym, przybierającym rozmaite formy artyzmem - nietypowej ambientowej muzyki, wierszy recytowanych przez bliżej nieokreślone istoty czy samej konstrukcji świata. Sny w Tension (częściowo jak w Neverwiner Nights 2: Maska Zdrajcy, jednakże za pomocą innych zabiegów) są naznaczone mistycyzmem uzyskanym dzięki naciskom na wiedzę tajemną (nie nazwaną w ten sam sposób, lecz wyznaczoną poprzez określanie wielu tematów tabu) oraz umiejętności tworzenia barw, czy nazwy umiejętności (na przykład grafem rytuału). Wątkom tajemnym towarzyszy erotyzm, tworząc w ten sposób sensualne doświadczenia. Część graczy może odczuwać podczas rozgrywki atmosferę oniryzmu wskutek powolnego tempa gry oraz wrażenia, że postać gracza lewituje, przemieszcza się w krainie Niebytu nieco zawieszona nad ziemią. Oniryzm jest wzmocnionym wizualnym przedstawieniem miejsc niczym z malarstwa Zdzisława Beksińskiego - który także tworzył „tak jak gdyby rejestrował marzenia i sny" (Beksiński 1978: 10). Twórcy nawiązują do snów także w warstwie tekstualnej, przytaczając na przykład utwór Luísa de Camões:

Indziej wciąż śnimy i przemijamy

Czas powiekom naszym przydaje zwidzenia

Nieboskłon sny spija i wizje przywdziewa

Świat wciąż nowymi widzisz barwami.

Samoistny posąg wokół rośnie

Niepomny nadziei płonnej niezaznanej

Radości w żałobny całun przyodzianej

Tylko szata po niej wciąż zostaje 
Uchodząca zima mrozu gniew łagodzi

Wciąż świat wiosny młodość na powrót przywdziewa

Choć prawem niezmiennym zniknie w ziemi

Radość nie osuszy łez spod firmamentu

I nie zdolna wstrzymać przemijania czasu

Jeśli sami świata nie zmienimy.

Wiersz przedstawia sny jako profetyczne, a zarazem związane z tanatycznymi wizjami, które dotyczą zniszczenia i niechybnie upływającego czasu. Mowa w nim również o zadaniu polegającym na zmianie świata, które wydaje się bardziej niż trudne; ukazane jest jako coś przytłaczającego czy nawet niemożliwego. Można powiedzieć, że atmosfera wiersza napawa poczuciem rezygnacji, smutku, a nawet lęku. Nie bez powodu podmiot liryczny wspomina także o pewnej cykliczności, podkreślając w ten sposób wpisaną w świat nieuniknioność śmierci wspomnianego „zniknienia w ziemi”.

Tension łączy więc ludyczność i zabawę ze sztuką, pośrednio także z filozofią, która wiąże się z wyrazem artystycznym wyróżniającym dany okres w historii człowieka, analizą, interpretacją tego, co kulturowe, oraz charakterystyczne dla miejsca i czasu. Umieszczenie snu w kontekście takich elementów nadaje mu wyraźnego zabarwienia artystycznego.

\section{Uwrażliwienie poprzez sen i strach - na podstawie gry wideo Among The Sleep}

Ostatnią analizowaną grą jest Among The Sleep - gra przygodowa niekiedy nazywana interaktywnym horrorem. Opowiada historię z perspektywy dziecka, które pozostaje samo (prawie - bo towarzyszy mu pomocny pluszak) w pokoju. Nastaje noc, a wraz z nią wszystko coraz bardziej zaczyna przypominać koszmar. Historia i lokacje są tak skonstruowane, że gracz - pomimo swojej (domniemanej) dojrzałości - czuje strach wywołany dziwnymi cieniami, ciągnącymi się do samej podłogi pokracznymi płaszczami i wieloma innymi codziennymi rzeczami. Fakt obrania przez twórców koncepcji nocnej mary sprawia, że odbiorca sam nie wie, co jest rzeczywiste, a co jest snem.

Fabuła dotyczy dziecięcych obaw związanych z matką, która pojawia się epizodycznie, by w dalszej części gry ujawnić się jako opresyjna i budząca grozę siła. Okazuje się, że potwór, przed którym uciekało dziecko, był koszmarem o matce oraz jej alkoholizmie, krzykach, problemach, a wszystko to, co dziecko napotkało na swojej drodze, było senną (czy raczej koszmarną) interpretacją tego, co codzienne i napawające strachem.

Sen w grze pojawia się jako w roli uwrażliwiającej wizji i tak jak literatura (Nyhus 2012) (czy inne teksty kultury) obrazuje to, co budzi w odbiorcach trudne emocje, przełamuje tabu i jednocześnie "pokazuje pewien problem światu” oraz nakłania do dyskusji. Z pedagogicznego punktu widzenia powstają warunki do rozwoju dyskursu oraz detabuizacji. Przełamanie milczenia na tematy takie jak alkoholizm, cierpienie, śmierć pozwala na pracę nad rozumieniem czy analizą ludzkich, społecznych słabości (Nilsson 2012). Jednocześnie gra wychodzi poza rozmowę o tabu z dziećmi - proponuje także rozmowę z dorosłymi, opiekunami, 
członkami społeczeństwa, bo to właśnie społeczeństwo stygmatyzuje zjawiska jako coś trudnego i niepokojącego.

Tutaj warto zadać sobie pytanie, czy sny są tematem tabu. W pewnym sensie tak, bo wiążą się nierzadko z silnymi emocjami. Budzą lęk (obrazują go) - na przykład przed utratą bezpieczeństwa, utratą czegoś lub kogoś. Mało kto z chęcią dzieli się snami silnie sensualnymi, które odzwierciedlają największe lęki. Opowieści o snach i koszmarach umożliwiają oswojenie strachu, eksternalizację wewnętrznych obaw i na swój sposób przyzwyczajenie. To jedna z podstawowych form redukcji lęku - tuż obok zetknięcia się z obiektem lęku i skupieniu na przebiegu sytuacji (Kępiński 2012), gdyż jest wykonaniem czynności obcowania z wizją problemu. Oczywiście to wymaga czasu, a pojedynczy, przerażający sen to zbyt mało, jednak mnogość okazji do stanięcia twarzą w twarz z tabu i lękiem może być wstępem, okazją do „przerobienia” problemu - zwłaszcza, jeśli do zetknięcia z nim dochodzi z perspektywy bezpiecznego fotela (Kruszelnicki 2010). Zdaje się to tłumaczyć popularność rozmaitych przesądów i konwencji związanych z tłumaczeniem snów. Chaos i niepokój są więc ubierane w skonwencjonalizowane formy tłumaczenia treści marzeń sennych, zaś ich objaśnianie staje się domeną albo określonych autorytetów (wieszczów, duchownych, wróżbitów), albo znaczeń utrwalonych przez praktykę kulturową, na przykład w postaci senników czy przekazywanych ustnie przekonań co do określonych symboli i treści obecnych w snach. Już Biblia, opowiadając dzieje patriarchy Józefa, przypisuje jego awans społeczny i zdobytą przezeń władzę zdolności objaśniania marzeń sennych, będącej rzekomo darem pochodzącym wprost od Boga. Umiejętność kojenia lęków i obaw związanych z kontaktem ze światem snów staje się synonimem mądrości oraz cenionym społecznie talentem. Nawet dziś w wielu domach można odnaleźć różne wydania książek poświęconych tłumaczeniu marzeń sennych, zaś internet stał się dogodną platformą wymiany informacji i poglądów na ich temat. Również w grach zrozumienie snów może stanowić istotną część fabuły. Odkrywanie znaczeń onirycznych wizji może zostać wręcz jednym z kluczowych elementów rozgrywki.

Among The Sleep oferuje więc senne okiełznanie obiektu lęku, problemu. Sen ma na celu podkreślenie (przez wyolbrzymienie, przedstawienie obaw w najgorszej możliwej formie) wagi sprawy społecznie drażliwej i trudnej. W ten sposób kontratakuje narastającą tabuizację społeczną.

\section{Zakończenie}

Oniryczne inkarnacje w grach wideo na nowo unieśmiertelniają sny. Utrwalają je na sposób cyfrowy i interaktywny, przypisując im niekiedy funkcje i cechy znane odbiorcom z innych tekstów kultury oraz wymiarów codzienności.

Tak jak w znanych dziełach kultury sny cechuje profetyzm, tanatyzm, groza, sensualność, erotyka, intymność, mistycyzm, fantazyjność. Ukazuje to, że sen w rozumieniu człowieka jest czymś sakralnym, ale w swojej świętości równie pięknym, co budzącym lęk. Niekiedy mogą być rozumiane jako fantazja, której ziszczenie może zakończyć panujący stan rzeczy czy postrzeganie rzeczywistości. Sen jest formą kompromisu pomiędzy uporządkowaniem a chaosem ludzkiego życia (Caillois 1973). Odpowiada na potrzebę pojednania sfery społecznych 
Tabela 1. Podsumowujące przedstawienie funkcji i cech snów $\mathrm{w}$ analizowanych grach wideo

\begin{tabular}{|c|c|c|c|c|}
\hline & $\begin{array}{l}\text { Seria Baldur's } \\
\text { Gate }\end{array}$ & $\begin{array}{c}\text { Neverwinter Nights 2: } \\
\text { Maska Zdrajcy }\end{array}$ & Tension & Among the Sleep \\
\hline $\begin{array}{c}\text { Funkcje } \\
\text { snu }\end{array}$ & $\begin{array}{l}\text { - profetyczna } \\
\text { - wspomnienia } \\
\text { i przypomnie- } \\
\text { nia } \\
\text { - komentarza }\end{array}$ & $\begin{array}{l}\text { - pobudzanie intymności } \\
\text { - stwarzanie okazji } \\
\text { i przestrzeni do fan- } \\
\text { tazjowania i wspomi- } \\
\text { nania }\end{array}$ & $\begin{array}{l}\text { - wzmocnienie } \\
\text { artystycznego } \\
\text { doświadczania }\end{array}$ & $\begin{array}{l}\text { - uwrażliwienia } \\
\text { - wywołania strachu po- } \\
\text { przez wizualne wypacze- } \\
\text { nie rzeczywistości przy } \\
\text { zachowaniu realnych } \\
\text { obaw } \\
\text { - połączenie snu i jawy }\end{array}$ \\
\hline $\begin{array}{l}\text { Cechy } \\
\text { snu }\end{array}$ & $\begin{array}{l}\text { - mrok } \\
\text { - niepokój } \\
\text { - lęk } \\
\text { - agresja } \\
\text { - doniosłość } \\
\text { - mistycyzm }\end{array}$ & $\begin{array}{l}\text { - romantyczność } \\
\text { - mistycyzm } \\
\text { - zmysłowość } \\
\text { - tajemniczość } \\
\text { - tanatyzm }\end{array}$ & $\begin{array}{l}\text { - mrok } \\
\text { - mistycyzm } \\
\text { - powolność } \\
\text { - tanatyczność }\end{array}$ & $\begin{array}{l}\text { - mrok } \\
\text { - groza } \\
\text { - fantazyjność }\end{array}$ \\
\hline
\end{tabular}

Źródło: opracowanie własne.

oczekiwań i sfery emocjonalnej jednostki. Stąd właśnie jego groźny urok. Przestrzeń snu ukazuje się jako miejsce, gdzie to, co powszednie, łączy się z tymi elementami życia kulturowego, których na co dzień wolelibyśmy nie dostrzegać; sferą ryzyka, w której najlepsze i najgorsze tendencje znajdują swe ujście i mają wolność, by przemówić. Ale może też być wręcz przeciwnie - sny mogą być fantazją. Podniecającym, upragnionym bodźcem zachęcającym do tego, by sięgnąć po to, co obiecujące; przepowiednią spełnienia - czy to realnego, czy pozornego, to mimo wszystko na tyle kuszącego, że duża część ludzi jest skłonna podjąć ryzyko i spróbować. Przedstawienia snów są ambiwalentne, mogą ukazywać lęk, ale także kusić sukcesem. Są nieokiełznaną i wolną myślą, mogąca zarówno niepokoić, niszczyć, jak i budować.

\section{Literatura:}

Beksiński Z., 1978, Sfotografować sen [rozmowa przeprowadzona przez J. Czopika], „Tygodnik Kulturalny" nr 35.

Bogost I., 2007, Persuasive Games. The expressive power of videogames, Cambridge: MIT Press.

Busse-Brandyk A., Chmielewska-Łuczak D., 2009, Narracyjne gry fabularne jako droga do nieświadomości, „Homo Ludens” nr 1, http://ptbg.org.pl/HomoLudens/bib/8/ [dostęp: 24.02.2016].

Caillois R., 1973, Żywioł i ład, wyb. A. Osęka, tłum. A. Tatarkiewicz, Warszawa: Państwowy Instytut Wydawniczy.

Cielecka M., 2014, Brzemię interaktywności - erotyka i seksualność w grach komputerowych, „Replay. The Polish Journal of Game Studies" nr 1.

Cunningham E., 2004a, Córka mrocznego Elfa, tłum. P. Kucharski, Warszawa: Isa

Cunningham E., 2004b, Splatane sieci, tłum. P. Lewandowska, Warszawa: Isa.

Eliade M., 2013, Kowale i alchemicy, Warszawa: Aletheia.

Freud S., 1996, Objaśnianie marzeń sennych, tłum. R. Reszke, Warszawa: Wydawnictwo KR.

Hall C.S., Lindzey G., Campbell J.B., 2010, Teorie osobowości, tłum. J. Kowalczewska, J. Radzicki, M. Zagrodzki, Warszawa: PWN.

Kępiński A., 2012, Lęk, Kraków: Wydawnictwo Literackie. 
Kruszelnicki M., 2010, Oblicza strachu. Tradycja i wspótczesność horroru literackiego, Torun: Wydawnictwo Adam Marszałek.

Nilsson U., 2012, Rozmowa na tematy tabu może pomóc dzieciom [w:] Tabu w literaturze i sztuce dla dzieci, red. B. Sochańska, J. Czechowska, Warszawa: Duński Instytut Kultury, Poznań: Media Rodzina.

Nyhus S., 2012, Niewidzialne dzieci, depresyjne matki i krzyczący ojcowie [w:] Tabu w literaturze i sztuce dla dzieci, red. B. Sochańska, J. Czechowska, Warszawa: Duński Instytut Kultury, Poznań: Media Rodzina.

Prósinowski P., 2015, To, co męskie, to, co kobiece. Konstrukty ptci i seksualności w grach komputerowych [w:] Codzienność, performatywność, demokracja: pedagogika wobec norm życiowych i problematyki nienormatywności, red. L. Kopciewicz, B. Simlat-Zuk, Gdańsk: Wydawnictwo Naukowe Katedra.

Prósinowski P., Ranachowska J., 2014, Męskość na waszych ekranach: konstrukty mężczyzn i ich seksualności w komputerowych grach fabularnych, filmach i reklamach, "Ars Educandi" t. 11.

Szeja J.Z., 2004, Gry fabularne - nowe zjawisko kultury wspótczesnej, Kraków: Rabid.

Topp I., Fereński P.J., Nahirny R. (red.), 2014, Sny w kulturze. Szkice dedykowane Profesorowi Stefanowi Bednarkowi, Warszawa-Wrocław: Wydawnictwo Korporacja Polonia.

Gry wideo:

BioWare, 1998, Baldur's Gate II, CD Projekt.

BioWare, 2000, Baldur's Gate, CD Projekt.

BioWare, 2009, Dragon Age: Poczatek, Electronic Arts Polska.

BioWare, 2011, Dragon Age II, Electronic Arts Polska.

BioWare, 2014, Dragon Age: Inkwizycja, Electronic Arts Polska.

Ice-Pick Lodge, 2008, Tension, Techland.

Krillbite Studio, 2014, Among The Sleep, Krillbite Studio.

Obsidian Entertainment, 2007, Neverwinter Nights 2: Maska Zdrajcy, CD Projekt.

\section{Abstrakt}

Ludzkość zawsze przywiązywała dużą wagę do snów oraz onirycznych wizji. W miarę rozwoju cywilizacji wizerunek snów przenosił się na coraz to nowsze media: obrazy plastyczne, literaturę, filmy. Sny pojawiają się jako znaczące także w branży gier wideo. Nierzadko są kluczowe dla fabuły. Deweloperzy, osoby odpowiedzialne za projekt gry, twórcy tekstów/dialogów przenoszą swoje rozumienie, popularne wizje snów do swoich produkcji; adaptują ich codzienne oraz mityczne cechy, eksponując sny w skonkretyzowany sposób, naprowadzający na konkretne interpretacje tegoż zjawiska. Celem artykułu jest dekonstrukcja tychże ekspozycji, wirtualnych konstrukcji snów i nocnych wizji w wybranych grach wideo oraz ukazanie znaczeń nadawanych snom przez twórców gier.

\section{Słowa kluczowe}

gry wideo, game studies, analiza tekstu kultury, wirtualna rzeczywistość, sny

\section{Summary}

\section{Oneiric Incarnations: The Construction of Dreams in Selected Video Games}

Humanity always considered dreams and oneiric visions significant. Along with development, the image of dreams was presented in different media: plastic arts, literature, films. Dreams appear also in video games. They are often presented as significant, in some 
situations even essential for the story to move on. Developers, designers, dialogue writers devolve their understanding of dreams to their productions; they include popular vision of dreams in their games. Developers also adapt both everyday and mythical features of dreams thus they present games in a specific pattern; they elicit specific interpretations of their constructs. The aim of this article is to deconstruct virtual expesition of dreams in specific video games, as well as description of meanings engraved in dreams inside analysed games.

\section{Keywords}

video games, game studies, analysis of cultural text, virtual reality, dreams 
